\title{
Anàlisi de les transicions juvenils des de la perspectiva de gènere: entre el pes del cicle de vida $\mathbf{i}$ el canvi generacional
}

\author{
Análisis de las transiciones juveniles desde la perspectiva \\ de género: entre la influencia del ciclo vital y el cambio \\ generacional
}

Universitat Autònoma de Barcelona. Centre d'Estudis Sociològics sobre la Vida Quotidiana i el Treball (Quit-Uab) . Institut D'Estudis del Treball (IET-Uab)

Artículo recibido: 3 junio 2014

Solicitud de revisión: 5 noviembre de 2014

Artículo aceptado: 16 enero 2015

\section{Resum}

L'article presenta una aproximació a la transició educativa, laboral, domiciliar i familiar de les persones joves des de la perspectiva de gènere. L'objectiu és analitzar fins a quin punt la millora del nivell educatiu introdueix transformacions en el caràcter tradicionalment sexuat de les transicions cap a la vida adulta. L'anàlisi comença pel conjunt de factors estructurals que poden condicionar les transicions juvenils, si bé atribueix una influència central a l'etapa del cicle vital.A partir de les dades de l'Enquesta a la Joventut de Catalunya 2012, es conclou que l'efecte cicle vital limita l'efecte generacional en la transformació de les relacions de gènere entre la població jove.

Paraules clau:Transicions, treball, génere, cicle vital, generació

Analysis of youth transitions from gender approach: the limit of life cycle versus generational change

\begin{abstract}
This paper focuses on educational, employment, housing and family transitions of young people from the gender perspective. The aim is to analyze how the educational system introduces changes in the traditional gendered transitions to adulthood. For this purpose, it takes into account structural factors with special attention to the life cycle. Based on data from the Enquesta a la joventud de Catalunya 2012, the results show that the effect of life cycle limits the effect of the generation in order to change the gender relations between young people.
\end{abstract}

Keywords:Transitions, work, gender, life cycle, generation 


\section{INTRODUCCIÓ}

L'estudi de les transicions juvenils a la vida adulta es pot abordar des de diverses perspectives teòriques. Un dels principals debats sorgeix entorn de les aproximacions que es fixen en la capacitat d'agència individual envers les aproximacions que parteixen de la influència dels factors estructurals. Aquesta segona perspectiva teòrica es concreta segons es posi l'accent en els aspectes culturals, socials o econòmics per tal de descriure i explicar els patrons d'emancipació (Gil Calvo, 2002).Alguns autors analitzen els canvis culturals que suposen transformacions estructurals com l'allargament de la joventut (Arnett, 2004), altres es centren en anàlisis comparades a partir dels diversos contextos institucionals i polítics (Todd, 1995; Van de Velde, 2009). Al costat d'aquestes aproximacions focalitzades en la influència de les estructures -enteses en termes culturals i institucionals- sobre les transicions, des d'una perspectiva estrictament socioeconòmica, l'interès recau en analitzar com els orígens socials marquen el pas a la vida adulta.A la pràctica, aquests estudis identifiquen tipologies relatives a les diferents trajectòries de transició segons la influència que hi exerceixen les principals variables socioeconòmiques (Pollock, 2007; Serracant, 2009). En aquest sentit, la classe social, l'origen geogràfic i el gènere acostumen a ser les variables d'anàlisi més emprades. L'objectiu sempre passa per analitzar com aquestes condicions materials de partida afecten els processos d'emancipació dels joves.

L'anàlisi de les transicions juvenils des de la perspectiva de gènere s'inclou dins d'aquesta proposta. En concret, implica analitzar com el gènere condiciona les oportunitats dels joves durant l'etapa del cicle de vida que va de la dependència de la infantesa a la autonomia de la vida adulta. La pregunta de recerca és clara i senzilla: els joves i les joves disposen de les mateixes oportunitats per afrontar les transicions educativa, laboral, domiciliar i familiar?

La majoria d'estudis realitzats des de la perspectiva de gènere apunten un canvi generacional pel que fa a les desigualtats de gènere que tendeixen a decréixer entre els grups d'edat jove (Garcia i Merino, 2006; Moreno, 2009; Torns i Moreno, 2009). El punt d'inflexió d'aquesta tendència és la igualtat d'oportunitats en l'accés a l'educació. L'augment del nivell educatiu de les joves té conseqüències positives sobre les seves trajectòries laborals i provoca una ruptura amb el discurs que vincula els rols de gènere a les responsabilitats familiars. Per exemple, en el context de l'Estat espanyol, a diferència de les generacions nascudes durant el franquisme, les ge- 
neracions de dones joves filles de la democràcia projecten expectatives vitals vinculades al que tradicionalment s'ha considerat l'esfera pública de la societat (Martin Serrano, 1994; Alberdi, 2000; Gil Calvo, 2002).

Malgrat aquest canvi generacional en la formulació del projecte de vida, diversos estudis també apunten que les desigualtats de gènere entre la joventut decreixen però no desapareixen.Tal com explica Carrasquer (1998), el model tradicional de l'home guanyador de pa i la dona mestressa de casa no reflexa la realitat de la joventut, principalment, pel canvi en les pautes de comportament femenines i no masculines. Al rerefons d'aquesta desincronització en el ritme de canvi, persisteix la desigual distribució del treball domèstic i familiar. Per aquesta raó, el cicle de vida es converteix en una variable clau per analitzar les condicions de vida de la joventut des de la perspectiva de gènere. El fet d'estar emancipat, viure en parella i tenir fills menors afecta de manera diferent a les trajectòries de transició educativa i laboral dels joves i les joves. Sorgeix, doncs, el debat teòric entorn del pes que exerceixen el factor generacional i el factor cicle de vida a l'hora d'explicar les transformacions en les transicions juvenils cap a la vida adulta. Com expliquen Salvadó i Serracant (2003), aquesta discussió planteja una confrontació entre els components estructurals o conjunturals del canvi. Per tot plegat, resulta de gran interès aprofundir en l'anàlisi sobre l'efecte generacional i l'efecte cicle de vida per tal d'estudiar les diverses transicions cap a la vida adulta des de la perspectiva de gènere.

Amb l'objectiu de donar resposta a la problemàtica plantejada, el present article analitza les condicions de vida i les possibilitats d'accés als recursos (educació, treball i temps) de la joventut a Catalunya tot considerant el gènere i el cicle de vida com dues variables explicatives fonamentals. En concret, es descriuen i expliquen els desequilibris que encara existeixen entre els joves i les joves en els diferents àmbits de la vida quotidiana segons l'etapa del cicle vital en la qual es troben. Aquesta aproximació implica entendre que les diferències entre els homes i les dones no són fruit d'un innatisme biològic sinó resultat d'una construcció social que atribueix característiques diferenciades a allò masculí i femení. Mentre que el sexe fa referència a les diferències biològiques entre el mascle i la femella, el gènere fa referència a les diferències socioculturals que es construeixen a partir del sexe tot donant peu a les desigualtats entre els homes i les dones (Rambla et al., 2008). 


\section{METODOLOGIA}

L'article es basa en les dades de l'Enquesta a la Joventut de Catalunya 2012 (EJC12). EJC12 és una estadística oficial de la Generalitat de Catalunya que es realitza cada cinc anys i, en aquest cas, es tracta de la sisena edició. La seva grandària mostral és 3.000 joves i la unitat de mostreig és la persona d'edat compresa entre 15 i 34 anys resident a Catalunya. Per la selecció d'individus es van utilitzar dues variables d'estratificació: l'àmbit territorial (segons el Pla Territorial de Catalunya) i la grandària de població del municipi. El disseny mostral va ser mostreig bietàpic per conglomerats amb estratificació prèvia, on les unitats de primera etapa van ser els municipis i les unitats de segona etapa els joves a entrevistar (Serracant, 2013).

Pel que fa el qüestionari, l'EJC12 inclou preguntes sobre nou àmbits temàtics que afecten les condicions de vida i hàbits de la joventut: educació, treball, emancipació i família, ingressos i despeses, cultura i oci, salut, participació, polítiques socials, i llengua. La base empírica d'aquest article parteix d'una lectura transversal des de la perspectiva de gènere de les variables principals d'aquests àmbits temàtics i de les tipologies construïdes ad boc (Serracant, 2013). En aquest sentit, s'han realitzat un conjunt de creuaments estadístics bivariants i trivariants per tal d'analitzar el pes dels factors estructurals (gènere, nivell estudis, edat, situació laboral i emancipació) que poden condicionar les transicions juvenils. La perspectiva d'anàlisi emprada també considera les diferències existents dins del mateix col-lectiu d'homes i dones. Com s'ha dit en la introducció, l'anàlisi atribueix una especial rellevància al cicle de vida amb l'objectiu de matisar el sentit del canvi generacional en les relacions de gènere entre la població jove.

\section{ANÀLISI DE LES TRANSICIONS}

\subsection{La transició educativa}

La igualtat d'oportunitats per accedir a l'educació és una de les millors garanties d'equitat democràtica en la societat actual. Per aquesta raó, el declivi generacional en les desigualtats de gènere es relaciona amb l'augment del nivell educatiu de les dones (Garcia i Merino, 2006). D'ençà a la democràcia, s'estén la idea que el règim de benestar ha de facilitar per igual l'accés a l'educació dels fills i les filles. Tal com explica Flecha (2008), l'educació ha jugat a favor de les dones i un dels resultats és que, a princi- 
pis del segle xxI, el nivell d'estudis de les joves supera el dels joves. Les dades de l'ejc12 confirmen aquesta tendència: el 35,4\% de dones joves té estudis superiors davant del $23,8 \%$ d'homes joves. Es tracta d'una tendència que també s'observa en altres països europeus però el cas català i espanyol destaca per registrar una distància major (INJuve, 2012). Aquest gap explica les diferències en el nivell d'estudis obligatori on la presència dels joves (41,9\%) supera en més de deu punts a les joves (30,3\%). La major concentració de dones en els estudis superiors i d'homes en els obligatoris posa de relleu una tendència envers dues trajectòries educatives oposades segons el gènere: una trajectòria femenina d'horitzó educatiu universitari versus una trajectòria masculina d'horitzó educatiu obligatori (Gabarró, 2010; INJUVE, 2012).

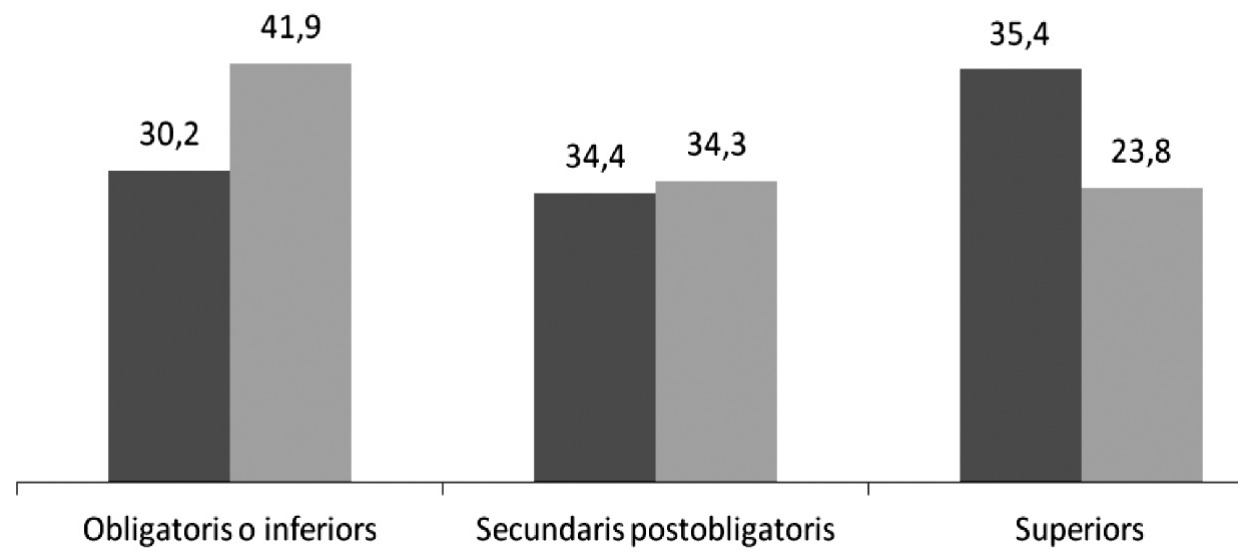

Font: Enquesta a la Joventut de Catalunya de 2012 (Agència Catalana de la Joventut)

Gràfic 1

Nivell d'estudis finalitzat segons sexe. Joves de 15 a 34 anys. Catalunya, 2012. Percentatge

Aquestes tendències es fan més evidents quan s'analitza el nivell educatiu tot considerant la relació actual amb els estudis. Mentre que els percentatges coincideixen entre la població que actualment està estudiant, les diferències en el nivell educatiu apareixen entre la població que no està estudiant. La majoria de dones joves que no estudia té estudis superiors $(50,5 \%)$, mentre que aquest és el cas de només el 33,8\% dels homes joves. 
Contràriament, el 42\% dels joves té estudis obligatoris o inferiors front el 26,3\% de les joves que es troben en aquesta situació. En aquest sentit, el darrer informe elaborat per INJUVE (2012) evidencia com el perfil de l'abandonament escolar té un rostre masculí. Unes dades que reforcen el dibuix de dues trajectòries educatives que difereixen segons el gènere $\mathrm{i}$ que confirmen un canvi en la transició educativa de les joves front la continuïtat en la transició educativa dels joves.

Tanmateix cal tenir present que existeix una tendència a reproduir les desigualtats intergeneracionals segons la formació i l'status professional dels pares (Moreno Mínguez, 2011). Des d'aquesta perspectiva, les dades de l'EJC12 subratllen diferències entre les mateixes joves catalanes que expliquen per què no totes segueixen trajectòries educatives superiors. Entre els factors més explicatius destaca el lloc d'origen i el nivell d'estudis dels pares, si bé ambdues variables actuen de manera diferent. D'una banda, entre els i les joves que tenen pares nascuts a l'estranger predominen els estudis obligatoris o inferiors de manera que sembla possible afirmar que la condició de fill/a immigrant afecta per igual als homes i les dones. D'altra banda, el nivell d'estudis dels pares apareix com una variable clau per explicar la millora en el nivell educatiu de les dones joves. El nivell d'estudis obligatoris o inferiors dels pares es reprodueix en major mesura entre les joves en comparació amb els joves. De la mateixa manera que el nivell d'estudis superior dels pares es reprodueix en major mesura entre les joves en comparació els joves. Com afirma Moreno Mínguez (2011), el nivell educatiu dels fills està clarament relacionat amb l'origen familiar. I caldria afegir que aquesta correlació es dóna, sobretot, en el cas de les dones.Atesa la relació entre el nivell educatiu i les condicions materials d'existència, semblaria que quan les dones joves tenen l'oportunitat d'estudiar ho fan més que els homes joves amb les mateixes oportunitats. Per contra, a falta d'oportunitats materials, els homes joves tenen més possibilitats d'estudiar que les dones joves. Aquest darrer cas es pot explicar pel pes del model tradicional de família en l'imaginari dels pares que, davant la manca de recursos, apostarien per l'educació dels fills en detriment de les filles. Unes expectatives que els fills i les filles assumirien com a pròpies a l'hora de pensar en el seu projecte de vida. 


\subsection{La transició laboral}

El paradigma del capital humà emfatitza la importància de la formació per a la inserció laboral de les persones (Becker, 1987). A partir d'aquesta proposta teòrica, caldria suposar que si les joves tenen un nivell educatiu més elevat en comparació als joves, tindran més fàcil l'accés al mercat de treball i gaudiran de millors condicions laborals (Salvadó, 2008). Les dades de l'EJC $12^{1}$ posen de relleu lleugeres diferències que entrarien en contradicció amb la teoria del capital humà i la perspectiva meritocràtica: la inactivitat femenina $(7,5 \%)$ és superior a la masculina $(4,7 \%)$ i l'ocupació masculina (51,3\%) és superior a l'ocupació femenina (48,9\%). Com s'explica aquesta tendència contradictòria?

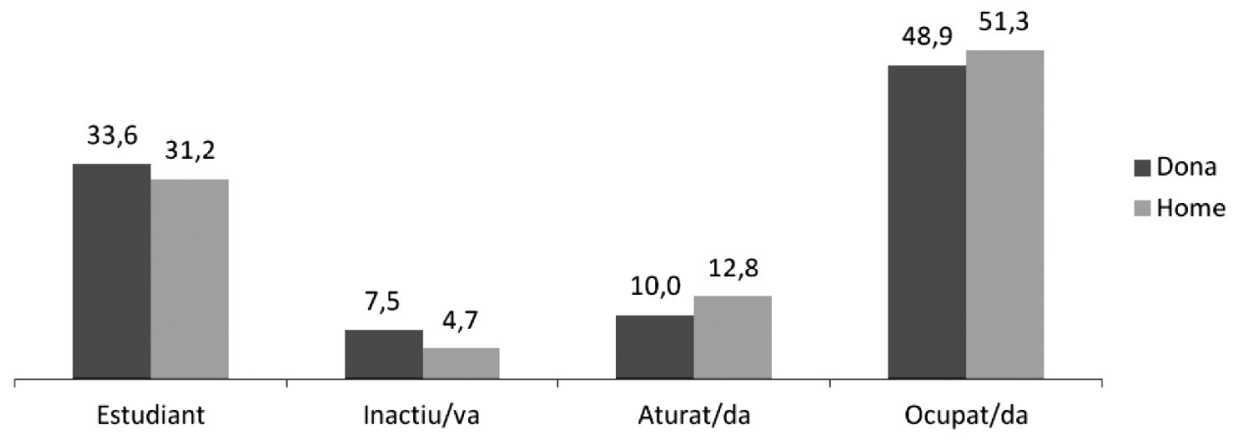

Font: Enquesta a la Joventut de Catalunya de 2012 (Agència Catalana de la Joventut)

Gràfic 2

Tipus d'activitat principal segons sexe. Joves de 15 a 34 anys. Catalunya, 2012. Percentatge

Com explica Agudo (2008), la incorporació de les joves al sistema universitari espanyol durant les últimes dècades no es tradueix en les mateixes proporcions al mercat de treball. Segons aquesta autora, la inserció laboral i el desenvolupament professional depenen dels estudis realitzats $i$ a factors discriminatoris aliens al mercat de treball. La dades relatives a

1 Cal tenir present que les dades sobre mercat de treball de l'ejc12 s'han recollit amb un tipus de qüestionari diferent de l'Enquesta de Població Activa (EPA) la qual cosa ajuda a explicar la manca de coincidència amb alguns dels resultats obtinguts i, per tant, recordar que no són comparables. 
l'activitat principal i secundària aporten alguna pista sobre les raons que donen compte de la manca de sintonia entre el nivell d'estudis i l'ocupació femenina en comparació a la masculina. Hi ha un 5,1\% de les dones joves que tenen com activitat principal les responsabilitats familiars, situació inexistent en el cas dels homes joves. Per contra, la suma dels percentatges d'atur masculí (12,8\%) superen lleugerament els femenins $(10,1 \%)$ tot invertint la tendència habitual abans de la crisi econòmica en què les aturades superaven els aturats. Entre les raons, cal contemplar la forta destrucció d'ocupació, d'ençà la crisi, en els sectors tradicionalment masculinitzats com la construcció. Però aquest canvi de tendència conviu amb una vella tendència femenina a través de la qual l'atur esdevé inactivitat (Torns et al., 2007). El global de les dades convida a pensar que per una part de les dones joves les responsabilitats familiars poden convertir l'atur en inactivitat, mentre que els homes es mantenen en la seva condició d'aturats en major mesura. En aquests casos d'absència d'ocupació, es pot pensar que actua el pes dels rols tradicionals de gènere. De fet, els estudis de tall qualitatiu apunten que algunes dones joves viuen l'atur com una oportunitat per la maternitat, mentre que els homes joves el perceben com un fracàs de la seva responsabilitat masculina com a «guanyador de pa» (Poveda, 2006; Moreno, 2009).

Les desigualtats de gènere també persisteixen entre la joventut ocupada en forma de qualitat de l'ocupació i posició en la jerarquia ocupacional igual que s'observa en l'informe elaborat per l'injuve relatiu al 2012. Malgrat que els percentatges de població ocupada no registren grans diferències segons el sexe, aquestes apareixen quan s'analitza la qualitat de l'ocupació. La temporalitat laboral, que afecta especialment als joves dins del mercat de treball, té més incidència entre les joves ocupades assalariades (29,0\%) que superen en més de sis punts als joves (23,3\%). Els contractes temporals estan molt vinculats a determinats subsectors d'ocupació (dins del sector serveis) on la presència de dones i persones joves hi és molt important. En aquests casos, les dones joves pateixen una doble discriminació.

En termes de segregació vertical, el primer que s'observa és que les dones són menys presents en les categories professionals més altes de la jerarquia laboral.Tot i que l'edat (la majoria de jovent està iniciant la trajectòria laboral) explica els baixos percentatges en els càrrecs de direcció i gerència, els joves pràcticament hi doblen les joves. En canvi, en la categoria de tècnics i professionals, les dones (40,3\%) superen en 7 punts els homes $(34,4 \%)$. Aquestes diferències recorden l'existència d'un sostre de 
vidre que es comencen a trobar algunes dones joves qualificades que persisteixen en la categoria de tècnics i professionals malgrat que potser podrien ocupar algun càrrec de direcció o gerència (Torns et al., 2007).

\section{Taula 1}

Categoria professional segons sexe. Joves ocupats de 15 a 34 anys. Catalunya, 2012. Percentatges

\begin{tabular}{|l|c|c|c|c|c|}
\hline \multicolumn{1}{|c|}{ Sexe } & $\begin{array}{c}\text { Directors i } \\
\text { gerents }\end{array}$ & $\begin{array}{c}\text { Professionals } \\
\text { i tècnics }\end{array}$ & $\begin{array}{c}\text { Ocupacions que re- } \\
\text { quereixen mitjana } \\
\text { qualificació }\end{array}$ & $\begin{array}{c}\text { Ocupacions } \\
\text { elementals }\end{array}$ & Total \\
\hline Dones & 2,7 & 40,3 & 48,1 & 8,9 & 100,0 \\
\hline Homes & 4,3 & 34,4 & 50,6 & 10,7 & 100,0 \\
\hline Total & 3,5 & 37,3 & 49,3 & 9,8 & 100,0 \\
\hline
\end{tabular}

Font: Enquesta a la Joventut de Catalunya de 2012 (Agència Catalana de la Joventut)

Les dades de sobrequalificació reforcen l'evidència empírica sobre l'existència del sostre de vidre entre la joventut en la mesura que un 27,2\% de dones ocupades té un lloc de treball inferior a les seves qualificacions front el 19,5\% d'homes que es troben en aquesta situació. Sense dubte, la sobrequalificació és un fenomen que afecta a les generacions joves cada vegada més formades però amb més dificultats d'èxit professional (INJuvE, 2012). Tanmateix, les dades de l'ejc12 posen de manifest que el fet de ser dona augmenta el risc de veure's afectat per aquest fenomen social. Un risc que respon a la contradicció que suposa la millora del nivell educatiu femení en un moment de crisi econòmica i precarització del mercat de treball, però també, a una lògica laboral que segueix discriminant per raó de gènere.

Tal com s'ha apuntat en l'apartat anterior, les dones joves no comparteixen entre elles les mateixes oportunitats per fer front a la transició educativa, la qual cosa té conseqüències sobre la seva transició laboral. En aquest sentit, la tipologia d'ocupacions construïda a partir de les dades de l'ejc12 il-lustra el perfil sociològic de les diferents situacions ocupacionals (Serracant, 2013). La majoria de joves enquestades es reparteixen entre el 
grup 2 i 6 . El grup 2 recull el cas de persones assalariades dins del sector del comerç i la indústria amb estudis secundaris i sobrequalificació. El grup 6 recull la situació d'assalariats del sector públic amb estudis superiors sense sobrequalificació. S'observa que el nivell educatiu emergeix com l'element diferencial entre ambdues situacions. Un fet que, com s'ha dit, està estretament vinculat $\mathrm{amb}$ el nivell d'estudis i lloc de naixement dels pares. En aquest sentit, les dades confirmen que la transició educativa i laboral de les joves estan molt relacionades amb la classe social d'origen. Una anàlisi més aprofundida permetria analitzar fins a quin punt les possibilitats de mobilitat social encara són més altes entre els joves que les joves (Serracant, 2009).

Pel que fa la resta de grups, es detecten diferències de gènere vinculades a les segregacions que persisteixen en el mercat de treball. En termes de segregació hortizontal, d'una banda, s'observa un percentatge més elevat d'homes joves en el grup 1, que inclou persones amb baix nivell educatiu ocupades a jornada completa en el sector de la construcció, la indústria i l'hosteleria. I, d'altra banda, un percentatge més elevat de dones joves en el grup 5, que inclou persones amb baix nivell d'estudis ocupades a temps parcial en activitats administratives i serveis auxiliars. Més enllà de les diferències de sector, cal tenir present que el fet de treballar a temps parcial o complet té conseqüències sobre els ingressos i les cotitzacions. En termes de segregació vertical, el percentatge d'homes quasi triplica el percentatge de dones en el grup 4, que recull els joves més ben posicionats en el mercat de treball en càrrecs de direcció i gerència.

En resum, les dades confirmen que persisteixen les desigualtats de gènere entre la joventut en la mesura que la millora del nivell educatiu femení no ha equiparat les oportunitats per fer front a la transició laboral (Flecha, 2008; Agudo, 2008). Comparteixen el fet de ser joves i, per tant, de formar part d'un dels col-lectius més vulnerables dins del mercat de treball. Tanmateix, divergeixen entre ells en la mesura que la classe social i el gènere segrega les seves trajectòries laborals. D'una banda, la classe social exerceix una influència sobre el nivell educatiu que genera desigualtats dins del mateix col·lectiu de joves (Moreno Mínguez, 2011). Entre la joventut amb baix nivell educatiu s'observen les conseqüències de la segregació horitzontal tal com evidencien els grups 1 i 5 de la tipologia de situacions ocupacionals. D'altra banda, el gènere exerceix una influència més homogènia en la mesura que diferencia els joves de les joves. Malgrat que les dones tenen millor nivell educatiu que els homes i representen una major proporció de tècniques i professionals, estan pitjor situades en termes 
quantitatius (temporalitat, treball a temps parcial i ingressos) i qualitatius (menor accés a les posicions directives i sobrequalificació) dins del mercat de treball.

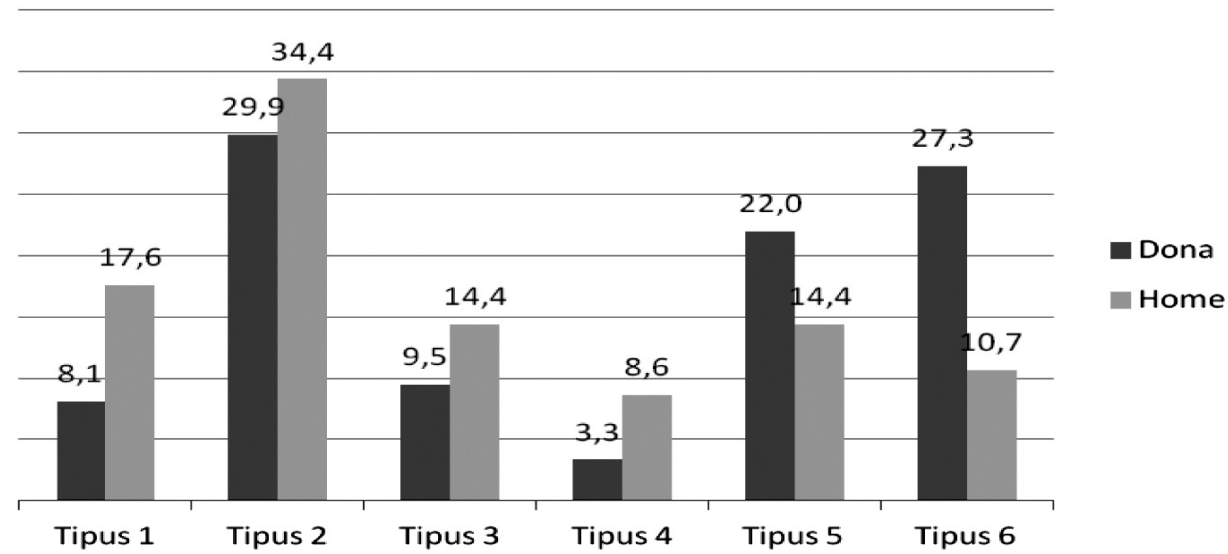

Font: Enquesta a la Joventut de Catalunya de 2012 (Agència Catalana de la Joventut)

\section{Gràfic 3}

Tipus d'ocupacions segons sexe. Joves ocupats de 15 a 34 anys. Catalunya, 2012. Percentatge

Per entendre què passa dins del mercat de treball cal saber què passa dins les llars on es distribueix el treball domèstic i familiar (Borderias et al., 1994). La influència de les responsabilitats domèstiques i familiars en l'activitat laboral de les dones queda palesa quan es considera el pes del cicle de vida, concretament a partir del fet de tenir fills. En aquest sentit, és cabdal considerar en quin moment es troben els joves i les joves respecte la transició domiciliar i familiar. Des de la perspectiva de gènere, s'entén que l'emancipació augmenta el volum de treball domèstic, així com el fet de tenir un fill fa aparèixer el treball de cura. La responsabilitat d'aquells treballs no remunerats encara recau, majoritàriament, sobre les dones joves, situant-les en una pitjor situació que els seus homòlegs masculins en relació al treball remunerat. Les dades de l'ejc12 així ho evidencien: mentre que en les parelles sense fills, les dones ocupades $(80,8 \%)$ superen als homes $(77,4 \%)$ i els homes inactius $(5,2 \%)$ superen a les dones $(3,3 \%)$; en les parelles amb fills disminueix 20 punts el percentatge de dones ocupades 
(60,2\%) i augmenta 20 punts el percentatge de dones inactives $(21,7 \%)$. Contràriament, el fet de tenir un fill no afecta els percentatges d'homes ocupats $(77,3 \%)$ i disminueix el percentatge d'homes inactius $(1,7 \%)$.

\section{Taula 2}

Activitat principal de la població que viu en parella segons sexe $\mathbf{i}$ per haver tingut fills. Joves de 15 a 34 anys que viuen en parella.

Catalunya, 2012. Percentatge

\begin{tabular}{|l|c|c|c|c|c|c|}
\cline { 3 - 7 } \multicolumn{2}{c|}{} & \multicolumn{5}{|c|}{ Activitat } \\
\hline \multirow{2}{*}{ Sexe } & Té fills & Estudiant & Inactiu/va & Aturat/da & Ocupat/da & Total \\
\cline { 2 - 7 } & Sí & 1,0 & 21,7 & 17,1 & 60,2 & 100,0 \\
\hline \multirow{2}{*}{ Homes } & No & 6,3 & 3,3 & 9,6 & 80,8 & 100,0 \\
\cline { 2 - 7 } & Sí & 3,1 & 1,7 & 17,9 & 77,3 & 100,0 \\
\hline \multirow{2}{*}{ Total } & No & 7,0 & 5,2 & 10,5 & 77,4 & 100,0 \\
\cline { 2 - 8 } & So & 2,05 & 11,7 & 17,5 & 68,75 & 100,0 \\
\hline
\end{tabular}

Font: Enquesta a la Joventut de Catalunya de 2012 (Agència Catalana de la Joventut)

Aquest augment de les joves que no treballen ni busquen feina s'explica, novament, pel pes dels rols tradicionals de gènere. La inactivitat per qüestions relacionades amb les responsabilitats familiars és la primera raó entre les dones que han abandonat la feina per decisió pròpia, mentre que és un fet inexistent pels joves inactius entre els quals predominen les qüestions personals i les relacionades amb la feina. S'observa, doncs, com finalitzada la transició educativa, els rols de gènere fan divergir les trajectòries laborals d'una part de la joventut. Com explica Moreno Mínguez (2010), en el procés de formació de la família i la seva gestió amb l'ocupació persisteixen les relacions de gènere tradicionals en un context de creixent individualització. 


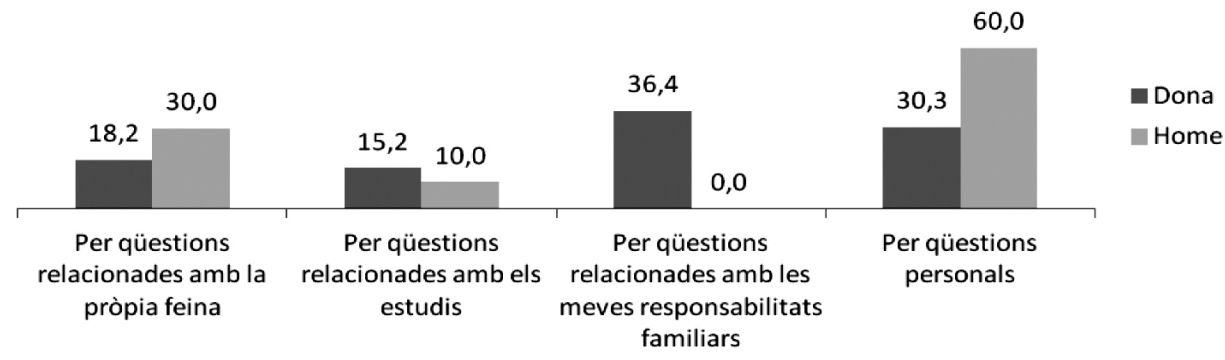

Gràfic 4

Motiu per deixar de treballar segons sexe. Joves inactius de 15 a 34 anys que van deixar l'ocupació que tenien. Catalunya, 2012. Percentatge*.

Les dones joves segueixen assumint la màxima responsabilitat del treball domèstic i del treball de cura, aspecte que condiciona la seva trajectòria laboral. L'ús del temps és un bon indicador per fer palesa aquesta manca d'igualtat d'oportunitats que dins del mercat de treball implica analitzar les hores dedicades al treball remunerat. Per aquesta raó, resulta interessant preguntar-se com varia la jornada laboral segons el moment del cicle de vida en què es troben les persones ocupades. D'entrada, s'observa que amb independència de la fase vital, els joves dediquen més temps al treball remunerat que les joves. En segon lloc, es fa palès com la influència dels rols tradicionals de gènere en la distribució del temps emergeix en el moment de tenir fills: els homes incrementen les hores dedicades al treball remunerat quan tenen fills, mentre que les dones en la mateixa situació disminueixen les hores dedicades al treball remunerat. Aquesta tendència explica per què el $48,2 \%$ de les joves espanyoles afirma que tenir fills suposa un obstacles per la vida professional front el 24,1\% dels joves (INJuve, 2012).

\footnotetext{
* Les dades són poc significatives estadísticament però s'ha optat per presentar-les atesa la seva importància analítica.

Font: Enquesta a la Joventut de Catalunya de 2012 (Agència Catalana de la Joventut)
} 


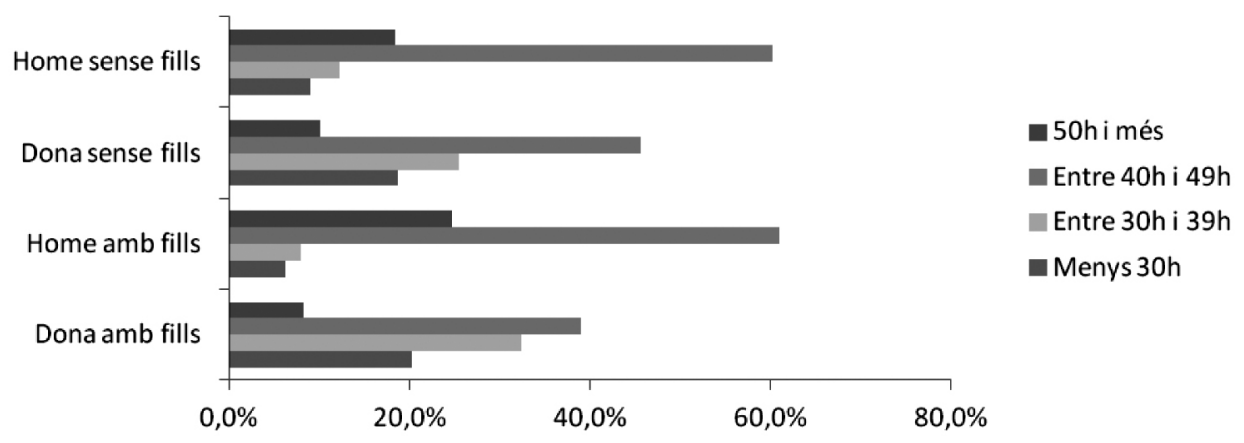

Font: Enquesta a la Joventut de Catalunya de 2012 (Agència Catalana de la Joventut)

\section{Gràfic 5}

Hores treball remunerat segons sexe i per haver tingut fills. Joves de 15 a 34 anys ocupats i que viuen en parella. Catalunya, 2012. Percentatge

\subsection{Transició domiciliar i familiar}

Com s'ha vist, el fet de viure en parella és un factor clau per explicar com i per què persisteixen les desigualtats de gènere entre les generacions joves. La distribució de les responsabilitats del treball domèstic i familiar entre els joves i les joves emancipades condiciona les seves possibilitats d'accés i actuació en els altres àmbits de la vida quotidiana, entre els quals destaca el laboral. Per aquesta raó, d'una banda, cal preguntar-se si en termes d'emancipació existeixen diferents patrons de comportament segons els gènere. I, d'altra banda, com es distribueix el treball domèstic i el treball de cura entre les persones joves que viuen en parella

En relació la primera qüestió, les dades de l'EJC12 reiteren el que apunten diversos estudis al llarg dels darrers anys (Serracant, 2013): les dones s'emancipen abans que els homes, el 54,4\% estan emancipades pel 45,6\% dels nois. El detall de les dades mostra que, majoritàriament, l'emancipació s'inicia a partir dels 25 anys, moment en què també apareixen les diferències de gènere ja que les joves s'emancipen abans que els joves. Si bé el patró de comportament generalitzat és que la transició domiciliar depèn de la transició educativa i laboral, sembla possible afirmar que en el cas dels joves és més freqüent allargar l'estada a casa dels pares malgrat tenir feina. 
Taula 3

Edat d'emancipació segons sexe. Joves emancipats de 15 a 34 anys.

Catalunya, 2012. Percentatge

\begin{tabular}{|l|c|c|c|c|c|}
\cline { 2 - 6 } \multicolumn{1}{c|}{} & \multicolumn{5}{c|}{ Edat d'emancipació } \\
\hline Sexe & $\begin{array}{c}\text { Dels } 15 \text { als } \\
19 \text { anys }\end{array}$ & $\begin{array}{c}\text { Dels } 20 \text { als } \\
24 \text { anys }\end{array}$ & $\begin{array}{c}\text { Dels } 25 \text { als } \\
29 \text { anys }\end{array}$ & $\begin{array}{c}\text { Dels } 30 \text { als } \\
34 \text { anys }\end{array}$ & Total \\
\hline Dones & 9,9 & 28,1 & 47,1 & 14,9 & 100 \\
\hline Homes & 9,7 & 28,7 & 43,6 & 17,9 & 100 \\
\hline Total & 9,8 & 28,4 & 45,35 & 16,4 & 100 \\
\hline
\end{tabular}

Font: Enquesta a la Joventut de Catalunya de 2012 (Agència Catalana de la Joventut)

La vida en parella també registra diferències segons el gènere. Malgrat que es tracta de la forma de convivència més comuna entre les persones emancipades, el percentatge de dones que viu en parella $(72,9 \%)$ és més elevat que el dels homes $(65,7 \%)$. Les raons d'aquesta diferència es poden cercar tant en una emancipació femenina més anticipada en edat, com en un major pes del model familiar tradicional entre les joves a l'hora d'emancipar-se.

Respecte la distribució de les tasques dins de la llar, les dades posen de manifest que la majoria de dones joves que viuen en parella dediquen més de dues hores diàries al treball domèstic, mentre que la majoria d'homes joves en la mateixa situació hi dediquen menys de dues hores. Als extrems d'aquestes tendències, destaca que un $20 \%$ de dones hi dedica més de 4 hores al dia, en contrast al $10 \%$ d'homes que directament no realitza treball domèstic. 


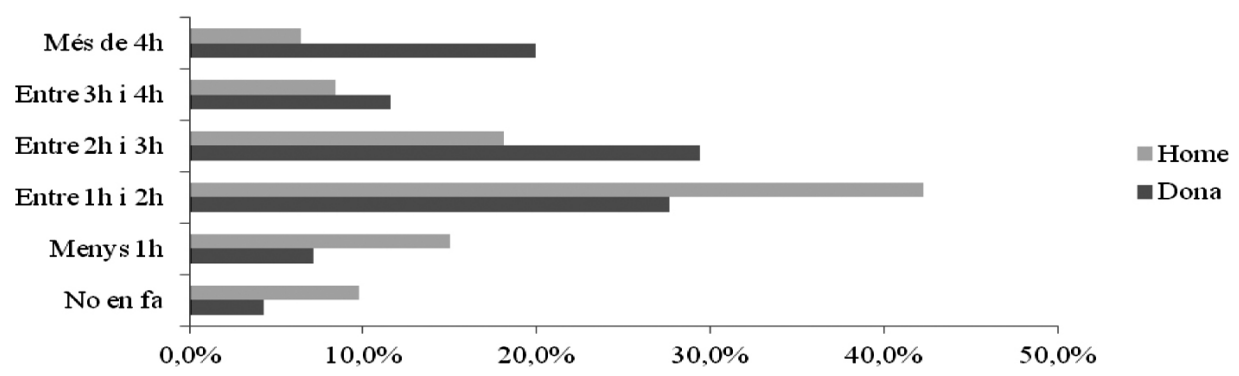

Font: Enquesta a la Joventut de Catalunya de 2012 (Agència Catalana de la Joventut)

Gràfic 6

Hores de treball domèstic en un dia laborable segons sexe. Joves de 15 a 34 anys que viuen en parella. Catalunya, 2012. Percentatge ${ }^{2}$

Sovint s'utilitzen les responsabilitats laborals per justificar les absències masculines dins l'àmbit domèstic, per aquesta raó és interessant analitzar la dedicació durant el cap de setmana. Com s'observa al gràfic següent, durant els dies festius globalment les dones segueixen dedicant més hores al treball domèstic, si bé augmenta la dedicació dels homes. Per tant, es pot pensar que la responsabilitat del treball domèstic sempre és present en la vida de les joves i només apareix en els joves en absència del treball remunerat. En aquest sentit, es podria apuntar l'existència d'un canvi generacional relacionat amb la major implicació masculina amb les tasques domèstiques durant el cap de setmana. Però, simultàniament, també caldria subratllar l'existència de la continuïtat generacional en la responsabilitat femenina de les tasques domèstiques quotidianes.

Ara bé, quan s'analitzen les dades segons l'activitat principal, la hipòtesi del canvi generacional perd poder explicatiu. D'entrada, les dones ocupades dediquen com a mitjana més hores al treball domèstic ( $1 \mathrm{~h} 50 \mathrm{~min}$ ) que els homes ocupats (1h $21 \mathrm{~min}$ ). Per tant, el treball remunerat no és garantia del repartiment igualitari del treball domèstic.Altrament, en absència d'ocupació, en situacions d'atur i inactivitat, augmenten les diferències entre homes $i$ dones tot posant de manifest el pes dels rols tradicionals de gènere.

2 En relació als trams d'hores, especificar que el grup «Entre $1 \mathrm{~h}$ i $2 \mathrm{~h}$ » contempla les dedicacions de 60 a 119 minuts, el grup «Entre $2 \mathrm{~h}$ i $3 \mathrm{~h}$ » les dedicacions de 120 a 179 minuts i el grup «Entre $3 \mathrm{~h}$ i $4 \mathrm{~h}$ » les dedicacions entre 180 i 239 minuts. 


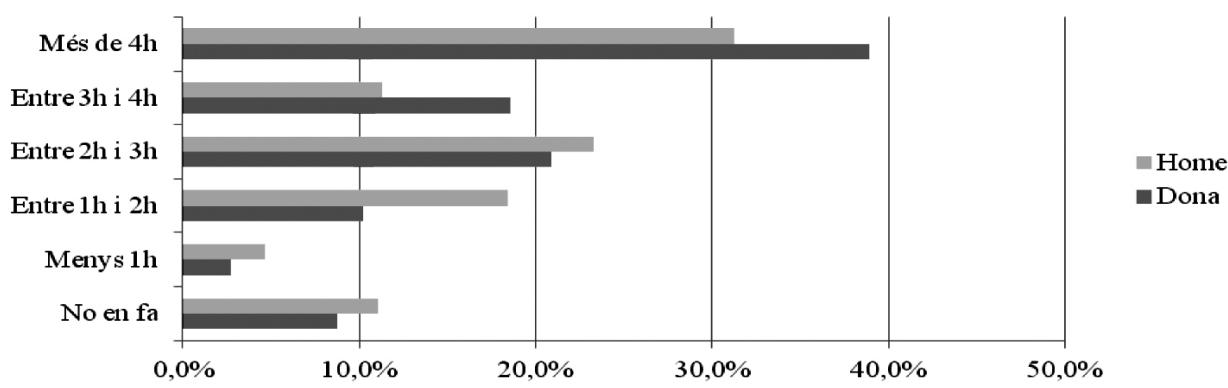

Font: Enquesta a la Joventut de Catalunya de 2012 (Agència Catalana de la Joventut)

\section{Gràfic 7}

Hores de treball domèstic el cap de setmana segons sexe. Joves de 15 a 34 anys que viuen en parella. Catalunya, 2012. Percentatge

\section{Taula 4}

Mitjana d'hores treball domèstic en un dia laborable segons sexe i per activitat principal. Joves de 15 a 34 anys que viuen en parella. Catalunya, 2012.

Mitjana d'hores diàries

\begin{tabular}{ccc}
\hline Sexe & Activitat principal & Treball domèstic \\
\hline \multirow{2}{*}{ Dones } & Estudiant & $2 \mathrm{~h} 56 \mathrm{~min}$ \\
\cline { 2 - 3 } & Ocupada & $1 \mathrm{~h} 50 \mathrm{~min}$ \\
\cline { 2 - 3 } & Aturada & $3 \mathrm{~h} 32 \mathrm{~min}$ \\
\cline { 2 - 3 } & Inactiva & $4 \mathrm{~h} 00 \mathrm{~min}$ \\
\hline Homes & Estudiant & $1 \mathrm{~h} 20 \mathrm{~min}$ \\
\cline { 2 - 3 } & Ocupat & $1 \mathrm{~h} 21 \mathrm{~min}$ \\
\cline { 2 - 3 } & Aturat & $2 \mathrm{~h} 07 \mathrm{~min}$ \\
\hline & Inactiu & $1 \mathrm{~h} 18 \mathrm{~min}$ \\
\hline
\end{tabular}

Font: Enquesta a la Joventut de Catalunya de 2012 (Agència Catalana de la Joventut)

Al costat de la situació laboral, el nivell d'estudis es manifesta com una variable clau per explicar les diferències que existeixen dins dels mateixos col-lectius dels joves i les joves. El nivell educatiu actua en sentit contrari 
segons el gènere (Moreno i Torns, 2008): en el cas de les joves, més nivell educatiu implica menys hores de dedicació al treball domèstic, mentre que en el cas dels joves més nivell educatiu implica més hores de dedicació al treball domèstic. Malgrat que la mitjana d'hores dedicades al treball domèstic no s'arriba a invertir en cap cas, les diferències de gènere són més petites entre les persones que tenen estudis superiors i més grans entre les persones que tenen estudis obligatoris. El conjunt d'aquestes tendències permet apuntar que el canvi generacional respecte la igualtat d'oportunitats per accedir a l'educació té efectes positius pel que fa a la distribució del treball domèstic entre els joves i les joves. Els homes amb estudis superiors són els que més temps dediquen a les tasques domèstiques, mentre que les dones amb estudis superiors són les que menys temps hi dediquen. Respecte aquest col·lectiu amb més formació, es pot pensar que hi ha una major corresponsabilització del treball domèstic entre els dos membres de les parelles, si bé també cal contemplar la possibilitat d'externalització d'una part de les feines de casa gràcies a un major poder adquisitiu.

\section{Taula 5}

Mitjana d'hores treball domèstic en un dia laborable segons sexe i per nivell d'estudis. Joves de 15 a 34 anys que viuen en parella. Catalunya, 2012.

Mitjana d'hores diàries

\begin{tabular}{|l|l|l|}
\hline \multirow{3}{*}{ Sexe } & Nivell d'estudis & Treball domèstic \\
\hline \multirow{4}{*}{ Dones } & Obligatoris o inferiors & $3 \mathrm{~h} 08 \mathrm{~min}$ \\
\cline { 2 - 3 } & Secundaris postobligatoris & $2 \mathrm{~h} 43 \mathrm{~min}$ \\
\cline { 2 - 3 } & Superiors & $1 \mathrm{~h} 52 \mathrm{~min}$ \\
\hline \multirow{2}{*}{ Homes } & Obligatoris o inferiors & $1 \mathrm{~h} 21 \mathrm{~min}$ \\
\cline { 2 - 3 } & Secundaris postobligatoris & $1 \mathrm{~h} 19 \mathrm{~min}$ \\
\cline { 2 - 3 } & Superiors & $1 \mathrm{~h} 38 \mathrm{~min}$ \\
\hline
\end{tabular}

Font: Enquesta a la Joventut de Catalunya de 2012 (Agència Catalana de la Joventut)

Al costat de les tendències generacionals, cal analitzar el pes del cicle de vida en la mesura que condiciona el volum del treball domèstic i del treball de cura a realitzar. En aquest sentit, s'observen dues tendències re- 
llevants. En primer lloc, que la responsabilitat de cura dels fills explica l'augment de la mitjana d'hores dedicades al treball domèstic amb independència del gènere. En segon lloc, que l'efecte increment que suposen els fills és més elevat en el cas de les mares (que augmenten més d'una hora el temps dedicat al treball domèstic) que en el cas dels pares (que augmenten la seva dedicació mitjana en 30 minuts). Aquestes dades confirmen, de nou, el pes de la variable cicle de vida per sobre del pes de la variable generació: és a dir, la maternitat i la paternitat accentuen les diferències de gènere entre la joventut. Més enllà de l'edat i el context social en què la joventut ha crescut, sembla que les circumstàncies vitals en termes de responsabilitats laborals i familiars subratllen les diferències entre els joves i les joves.

Taula 6

Mitjana d'hores treball domèstic en dia laborable segons sexe i per haver tingut fills. Joves de 15 a 34 anys que viuen en parella. Catalunya, 2012.

Mitjana d'hores diàries

\begin{tabular}{|l|c|c|}
\hline \multicolumn{1}{|c|}{ Sexe } & Fills & Treball domèstic \\
\hline \multirow{2}{*}{ Dones } & Sí & $2 \mathrm{~h} 57 \mathrm{~min}$ \\
\cline { 2 - 3 } & No & $1 \mathrm{~h} 43 \mathrm{~min}$ \\
\hline \multirow{2}{*}{ Homes } & Sí & $1 \mathrm{~h} 43 \mathrm{~min}$ \\
\cline { 2 - 3 } & No & $1 \mathrm{~h} 15 \mathrm{~min}$ \\
\hline
\end{tabular}

Font: Enquesta a la Joventut de Catalunya de 2012 (Agència Catalana de la Joventut)

Les desigualats de gènere persisteixen quan s'analitza el contingut de les tasques realitzades com a treball domèstic i familiar, així com la responsabilitat de les mateixes (Moreno, 2009). A partir de les dades de l'EJc12 s'observa que, d'una banda, les tasques relacionades amb la cuina i la neteja de la llar i de la roba es mantenen com a tasques feminitzades; la compra i les gestions apareixen com les tasques més compartides entre els dos membres de la parella; i les reparacions de la llar com una tasca absolutament masculinitzada. D'altra banda, el grau d'implicació varia segons aquesta divisió: la responsabilitat quasi exclusiva de les dones recau en les tasques més feminitzades i viceversa pel que fa les reparacions de la llar. 
En canvi, la compra i les gestions, són les tasques en que més distribució equitativa reconeixen subjectivament les persones enquestades. Aquesta divisió de tasques i responsabilitats no és casual, sinó que s'explica pels patrons i estereotips de gènere que persisteixen entre la joventut emancipada. Malgrat que els homes joves augmenten la seva implicació i responsabilitat en el treball domèstic, ho fan en aquelles tasques més senzilles i menys estigmatitzades socialment. La compra i les gestions de la llar tenen una dimensió social que ni la cuina diària ni la neteja de la llar i de la roba ostenten. A banda del component subjectiu de la satisfacció, aquesta divisió contribueix a invisibilitzar determinades tasques de la llar que les dones joves assumeixen, tal com varen fer les seves mares i àvies.

En el cas de la cura dels fills es manté la tendència d'una major responsabilitat femenina, si bé apareix com una de les activitats que amb més freqüència es reparteix de manera equitativa: el $24,3 \%$ de les dones i el $21,3 \%$ dels homes afirmen que s'ocupen de la cura dels fills més o menys per igual.Tanmateix, les dades de l'ejc12 mostren com la majoria de dones joves conserven el rol de principals cuidadores $(47,5 \%)$ a diferència de la minoria d'homes joves que es troba en aquesta situació $(7,1 \%)$. Novament es posa de relleu una major responsabilitat femenina vers el treball de cura que condiciona la disponibilitat de les dones vers el treball remunerat, tant pel que fa a les seves expectatives com pel que fa a la lògica del mercat laboral. Es constata el que Aguinaga (2004) explica en termes del preu que els fills suposa per a les joves en comparació els seus coetanis masculins.

Recuperant les dades sobre la transició laboral, es constata que la major responsabilitat femenina en la cura dels fills és una de les raons que explica perquè les dones joves estan pitjor situades que els homes joves dins del mercat de treball. La correlació entre la fecunditat i l'ocupació és més forta entre les dones que els homes (InJuve, 2012). Entre la població ocupada es mantenen les diferències de gènere respecte el grau d'implicació en la cura dels fills, sent elles les que assumeixen el rol principal. La interiorització de la responsabilitat d'aquest treball de cura s'evidencia encara més quan s'observa que entre la població aturada, el 63\% de dones diu ocuparse principalment dels fills front el $26,8 \%$ dels homes que es troba en aquesta situació. Per tant, sembla possible afirmar que en absència del treball remunerat, s'observa el pes de la socialització diferencial per raó de gènere entre les generacions joves en un moment cabdal del cicle de vital. De nou, l'atur apareix com una oportunitat per la maternitat en el cas de les dones joves però la paternitat no sembla justificar la inactivitat en el cas dels homes joves (Poveda, 2006). 


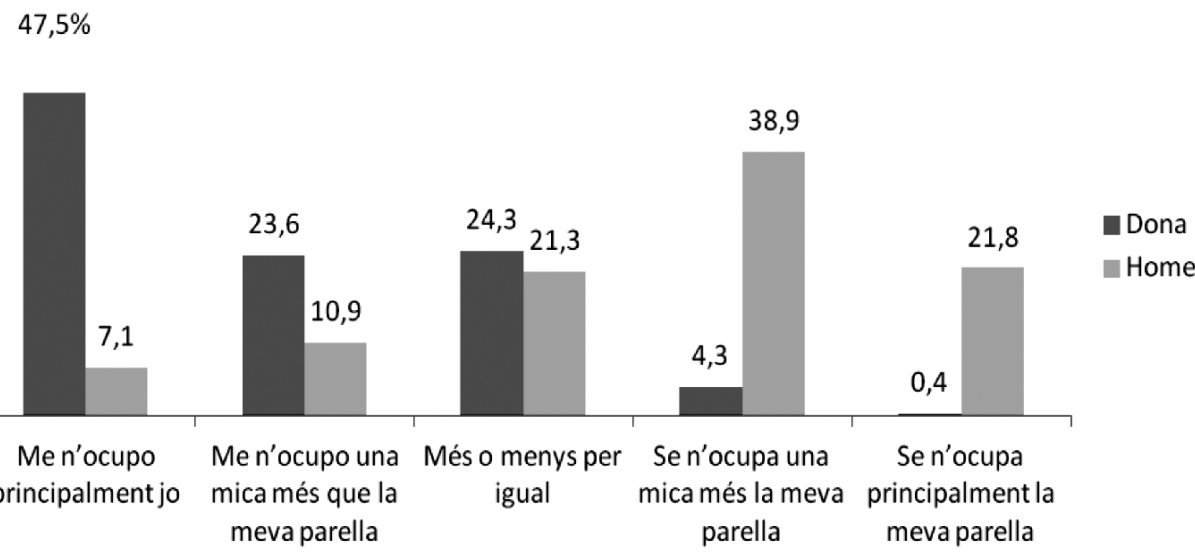

Font: Enquesta a la Joventut de Catalunya de 2012 (Agència Catalana de la Joventut)

Gràfic 8

Responsabilitat en la cura dels fills segons sexe. Joves de 15 a 34 anys que viuen en parella. Catalunya, 2012. Percentatge

\subsection{El cost temporal de les transicions}

La joventut és una etapa del cicle de vida on el temps lliure hi té un protagonisme rellevant. Es tracta d'un temps sense significat estructural que representa un espai de socialització i, alhora, un espai identitari on es desenvolupen determinats rols socials (Comas, 2000). Des de la perspectiva de gènere, hi ha dos aspectes rellevants perquè permeten analitzar les diferències entre els joves i les joves en relació a la disponibilitat de temps per l'oci i el contingut de les activitats realitzades. D'una banda, les activitats d'oci estan relacionades amb la disponibilitat de temps de lliure en disposició personal, és a dir, un temps lliure d'obligacions. La condició d'estudiant entre la joventut facilita disposar d'aquest temps en la mesura que no hi ha responsabilitats de treball ni familiars. D'altra banda, les activitats d'oci representen un canal d'expressió de les identitats juvenils que es reafirmen i relacionen a través de les activitats culturals i de lleure.Així doncs, cal esperar que la disponibilitat estarà condicionada per l'etapa del cicle vital i les responsabilitats domèstiques que comporta, mentre que el contingut pot reproduir determinats estereotips de gènere. 
En primer lloc, si es considera que la disponibilitat de temps per a l'oci està relacionada $\mathrm{amb}$ la freqüència amb que es realitzen les activitats de lleure i culturals, s'observa que la meitat de la població ho fa regularment i l'altra meitat esporàdicament. El grup d'edat entès com un indicador del cicle de vida és la variable explicativa d'aquesta divisió: entre la joventut, els més joves fan més oci que els més grans amb independència del sexe. Aquesta tendència es mostra coherent amb la realitat social si es considera que als 16 anys es disposa de més temps lliure i es té més necessitat de cercar canals per construir i expressar una identitat social en l'àmbit públic i relacional aliè a l'esfera laboral o familiar. Les diferències de gènere apareixen quan s'analitzen els resultats de la tipologia d'activitats d'oci (Serracant, 2013) ${ }^{3}$. L'oci relacional, cultural i digital són els tres grups més freqüents entre la població jove, si bé es distribueixen de manera diferent segons el sexe. Segons les dades de l'EJc12, en el cas de les joves, s'observa una major proporció del grup d'oci relacional (24\%), seguit de l'oci cultural $(15,1 \%)$ i finalment l'oci digital $(7,8 \%)$. En canvi, en el cas dels joves s'inverteix l'ordre i apareix l'oci digital $(22,7 \%)$ per davant de l'oci relacional $(16,5)$ i en darrer lloc l'oci cultural $(7,7 \%)$. Aquests percentatges posen de manifest una pràctica d'oci femenina caracteritzada per fer activitats de grup (sortir de nit, estudiar i fer esport) i culturals (lectura, música, cinema) i una pràctica d'oci masculina caracteritzada per la realització d'activitats digitals (lectura, comunicació, joc, descàrregues). L'existència d'aquests patrons de comportaments diferenciats està relacionada amb la influència de determinats estereotips de gènere on les relacions socials tenen un component més femení i les activitats tècniques un component més masculí.

Mentre que el contingut de les activitats d'oci està relacionat amb el sexe i el nivell d'estudis, la regularitat de les mateixes està relacionada amb

3 La tipologia permet classificar les persones joves segons les seves activitats culturals i d'oci. La tipologia està formada per cinc grups: el primer grup el formen joves que practiquen un oci relacional (anar a la discoteca, fer esport, sortir de nit, anar a concerts de música moderna, estudiar, quedar amb els amics, xatejar, participar en xarxes socials i descarregar-se films i musica d'Internet). El segon grup es caracteritza per pràcticament fer de tot, encara què destaca per la intensitat amb que realitza activitats d'oci cultural. El tercer grup també pràcticament fa de tot, excepte les activitats culturals, i destaca per la seva realització d'activitats d'oci digital. El quart grup (oci esporàdic) fa alguna activitat d'oci a casa i quan surt ho fa per viatjar, fer excursions, anar a actes religiosos o quedar amb els amics. I el cinquè grup es caracteritza per realitzar amb molt poca freqüència aquest tipus d'activitats d'oci. Pot veure's informació detallada de la tipologia al capítol de Cultura $i$ oci. 
el sexe i el cicle de vida, entenent que la presència o absència de responsabilitats laborals i familiars condiciona la disponibilitat de temps lliure per les activitats d'oci. Així, al costat del grup d'edat, l'emancipació actua com una variable molt explicativa a l'hora d'analitzar els resultats: la majoria de població emancipada es situa en les categories d'oci esporàdic i de baixa intensitat, mentre que la majoria de població no emancipada es situa en les altres tres categories. Des de la perspectiva de gènere, s'observa que l'emancipació afecta més a les dones que els homes: les no emancipades són més actives que els seus homòlegs masculins, les emancipades són menys actives però més esporàdiques que ells.

\section{Taula 7}

Tipus d'activitats d'oci segons sexe i situació d'emancipació. Joves de 15 a 34 anys. Catalunya, 2012. Percentatge

\begin{tabular}{|c|c|c|c|c|c|c|c|}
\cline { 3 - 8 } \multicolumn{2}{c|}{} & \multicolumn{7}{c|}{ Tipus d'activitats d'oci } \\
\hline \multirow{2}{*}{ Sexe } & $\begin{array}{c}\text { Emancipat/ } \\
\text { da }\end{array}$ & $\begin{array}{c}\text { Oci } \\
\text { relacional }\end{array}$ & $\begin{array}{c}\text { Oci } \\
\text { cultural }\end{array}$ & $\begin{array}{c}\text { Oci } \\
\text { digital }\end{array}$ & $\begin{array}{c}\text { Oci } \\
\text { esporàdic }\end{array}$ & $\begin{array}{c}\text { Oci de } \\
\text { baixa } \\
\text { intensitat }\end{array}$ & Total \\
\hline \multirow{2}{*}{ Dones } & Sí & 9,2 & 13,8 & 5,8 & 39,6 & 31,6 & 100,0 \\
\cline { 2 - 9 } & No & 41,6 & 16,9 & 10,1 & 18,8 & 12,7 & 100,0 \\
\hline Homes & Sí & 11,5 & 8,1 & 11,6 & 31,4 & 37,4 & 100,0 \\
\cline { 2 - 9 } & No & 21,3 & 7,3 & 33,1 & 21,9 & 16,4 & 100,0 \\
\hline
\end{tabular}

Font: Enquesta a la Joventut de Catalunya de 2012 (Agència Catalana de la Joventut)

La influència de la fase del cicle vital queda reforçada quan es té en compte la presència dels fills entre les persones que viuen en parella, entre les quals es redueix a percentatges testimonials la presència en els grups d'oci relacional, cultural i digital. Cal tenir present que la majoria de fills de les persones joves enquestades són menors que es troben en el període inicial de la seva vida i, per tant, requereixen molta atenció i dedicació per part dels progenitors. Un aspecte que afecta als homes i les dones, si bé sembla tenir una incidència més gran en el cas de les mares entre les quals el percentatge d'oci de baixa intensitat s'equiparen al d'oci esporàdic. La traducció d'aquestes xifres permet plantejar que per a moltes dones els 
fills suposen deixar de fer activitats d'oci a dins de casa i activitats culturals quan surten fora.Aquest canvi redueix el gap en relació les tipologies d'oci masculines, per bé que es tracta d'una reducció negativa al representar una pèrdua femenina de temps de lliure disposició personal atesa la responsabilitat de cura dels fills. Per a les dones joves, la transició domiciliar i familiar suposa un cost temporal major en comparació amb als seus homòlegs masculins.

\section{Taula 8}

Tipus d'activitats d'oci de la població segons sexe i per haver tingut fills. Joves de 15 a 34 anys que viuen en parella. Catalunya, 2012. Percentatge

\begin{tabular}{|c|c|c|c|c|c|c|c|}
\cline { 3 - 8 } \multicolumn{2}{c|}{} & \multicolumn{7}{c|}{ Tipus d'activitats d'oci } \\
\hline \multirow{2}{*}{ Sexe } & Té fills & $\begin{array}{c}\text { Oci } \\
\text { relacional }\end{array}$ & $\begin{array}{c}\text { Oci } \\
\text { cultural }\end{array}$ & Oci digital & $\begin{array}{c}\text { Oci } \\
\text { esporàdic }\end{array}$ & $\begin{array}{c}\text { Oci de } \\
\text { baixa } \\
\text { intensitat }\end{array}$ & Total \\
\hline \multirow{2}{*}{ Dones } & Sí & 1 & 3,3 & 3 & 46,7 & 46,1 & 100 \\
\cline { 2 - 8 } & No & 6,6 & 16,2 & 8,6 & 44 & 24,5 & 100 \\
\hline \multirow{2}{*}{ Homes } & Sí & 1,7 & 3,5 & 7,4 & 38 & 49,3 & 100 \\
\cline { 2 - 8 } & No & 7 & 10,5 & 10,5 & 30 & 42,2 & 100 \\
\hline \multirow{2}{*}{ Total } & Si & 1,3 & 3,4 & 5,2 & 42,3 & 47,7 & 100 \\
\cline { 2 - 8 } & No & 6,8 & 13,35 & 9,55 & 37 & 33,35 & 100 \\
\hline
\end{tabular}

Font: Enquesta a la Joventut de Catalunya de 2012 (Agència Catalana de la Joventut)

\section{CONCLUSIONS}

L'article presenta una aproximació a la transició educativa, laboral, domiciliar i familiar de les persones joves des de la perspectiva de gènere per tal d'analitzar fins a quin punt els joves i les joves disposen de les mateixes oportunitats per afrontar-les. Aquesta anàlisi ha tingut en compte el conjunt de factors estructurals que poden condicionar les transicions juvenils, si bé ha atorgat una especial rellevància al cicle de vida, amb l'objectiu de matisar el sentit del canvi generacional en les relacions de gènere entre la 
població jove. La recerca existent coincideix a l'hora d'apuntar una major igualtat entre els joves i les joves de les generacions joves gràcies a la igualtat d'oportunitats que suposa l'accés universal a l'educació (Garcia i Merino, 2006). Si bé, alguns d'aquests estudis també apunten límits en aquest procés de convergència de les transicions cap a la vida adulta (Carrasquer, 1998). Fins a quin punt el sistema educatiu introdueix transformacions en les transicions juvenils tradicionalment sexuades?

A partir de les dades de l'EJc12 es pot concloure que només existeix igualtat d'oportunitats en la transició educativa i, per tant, que persisteixen les desigualtats de gènere en la transició laboral, domiciliar i familiar. Les dones joves tenen un nivell educatiu més elevat que els homes joves però estan pitjor situades dins del mercat laboral (temporalitat, categoria socioprofessional, ingressos) que els seus homòlegs masculins. Les dones joves s'emancipen una mica abans que els homes joves però el treball domèstic i familiar està desigualment distribuït per raó de gènere. La persistència d'aquesta divisió sexual del treball dins l'àmbit domèstic és el que posa límits al canvi generacional que representa la millora del nivell educatiu de les joves. Una millora que no ha esdevingut la garantia de la igualtat d'oportunitats tal i com varen imaginar moltes famílies d'ençà de la democràcia, quan van oferir a fills i filles les mateixes possibilitats per estudiar. Aquestes famílies varen alimentar l'imaginari segons el qual l'educació es la millor garantia per la igualtat d'oportunitats en l'àmbit públic i es varen oblidar d'actuar igualitàriament en l'àmbit domèstic de la família.Tal com recorda Saraceno (1986), l'estructura sexuada de la vida quotidiana exerceix una influència molt gran sobre els projectes de vida de les generacions futures. El resultat és una socialització diferencial per raó de gènere que condiciona les maneres de viure i pensar la vida quotidiana entre els joves i les joves. En aquest sentit, cal apuntar dues qüestions. D'una banda, que existeixen diferències entre les joves molt vinculades al nivell educatiu. I, d'altra banda, que no totes les joves comparteixen les mateixes possibilitats per accedir a l'educació sent la classe social d'origen un element clau.

Contràriament a l'argument que defensen alguns autors sobre la potencialitat del canvi atribut a l'augmentat de l'escolarització de les noies (Baudelot i Establet, 1992), les dades de l'EJC12 posen de manifest els límits de la capacitat transformadora d'un sistema educatiu construit sobre un substrat sociocultural on persisteix la divisió sexual del treball.

En termes de projecte vital, les dades reforcen el que apunten altres estudis de tall qualitatiu (Borràs et al. 2012; Torns et al. 2013): el projecte 
vital dels joves s'articula entorn de la transició laboral, mentre que el projecte vital de les joves s'edifica segons la transició laboral i familiar. La combinació no és fàcil i sovint el pes de la transició familiar condiciona la transició laboral malgrat l'èxit en la transició educativa. Tot plegat s'evidencia quan les dades mostren la influència que el cicle de vida (a partir del fet de tenir fills) exerceix en tots els àmbits analitzats: educació, treball remunerat, treball domèstic i temps lliure.

En conclusió, es pot afirmar que les joves són les protagonistes del canvi generacional perquè la millora del nivell educatiu esdevé una garantia per la seva presència en l'àmbit públic. Alhora que els joves són els protagonistes dels límits d'aquest canvi generacional perquè continuen menys presents en l'àmbit domèstic en comparació amb les seves coetànies femenines. L'efecte cicle de vida limita l'efecte generacional pel que fa la transformació en les relacions de gènere entre la població jove: com més a prop estan els joves i les joves d'assolir l'autonomia de la vida adulta, més augmenten les diferències de gènere. Una conclusió que, inevitablement, s'ha de formular com a hipòtesi i que caldrà validar en els propers anys. En qualsevol cas, les dades de l'ejc12 permeten afirmar que entre la població jove que viu a Catalunya avui, la maternitat condiciona més les transicions juvenils que la paternitat.

\section{BIBLIOGRAFIA}

Agudo, Y. (2008): «Mujeres jóvenes hoy: el empleo de las tituladas superiores», Revista de Estudios de Juventud, 83. pp. 65- 101.

Aguinaga, J. (2004): El precio de un bijo. Los dilemas de la maternidad en una sociedad desigual, Debate, Barcelona.

Alberdi, I. (coord.) (2000): Les dones joves a Espanya, Col-lecció Estudis Socials 4, Barcelona, Fundació La Caixa.

ARnETT, J. (2004): Emerging Adulthood: The winding road from late teens through the twenties, Oxford, Oxford University Press.

Baudelot, C. i Establet, R. (1992): Allez les filles!, París, Éditions du Seuil.

BECKer, G. (1987): Tratado sobre la familia, Madrid, Alianza.

Borderias, C.; Carrasco, C. y Alemany, C. (1994): Las mujeres y el trabajo: rupturas conceptuales, Barcelona, Icaria.

Borràs V. i altres (2012): "Male Hegemony in Decline? Reflections on the Spanish Case», Men and Masculinities, 15 (4), pp 406-423. 
CARrasquer, P. (1998): “Jóvenes, empleo y desigualdades de género», Cuadernos de Relaciones Laborales, 11. Pp. 55-80.

Comas, D. (2000): Agobio y normalidad. Una mirada crítica sobre el sector «ocio juvenil» en la España actual, Madrid, Instituto de la Juventud.

Flecha, C. (2008): «Un lugar para las jóvenes en la educación», Revista de Estudios de Juventud, 83. pp. 47-64.

Garcia, M. i Merino, R. (2006): "Transición a la vida adulta: nuevas y viejas desigualdades en función del género», REIS, 113(06), pp. 115-162.

GABARRó D. (2010): ¿Fracaso escolar? La solución inesperada del género y la coeducación, Lleida, Ed. Boira.

Gil Calvo, E. (2002): «Emancipación tardía y estrategia familiar», Revista de Estudios de Juvenud, 58, pp.1-9.

INJUVE. (2012): Informe Juventud en España 2012. [http://www.injuve.es/ sites/default/files/2013/26/publicaciones/IJE2012_0.pdf]

Martín Serrano, M. (1994): Historia de los cambios y mentalidades de los jóvenes entre 1960 y 1990, Madrid, Instituto de la Juventud.

Moreno Mínguez, A. (2011): «La reproducción intergeneracional de las desigualdades educativas: límites y oportunidades de la democracia», Revista de Educación, 1.2011, pp. 183-206. [http://www.revistaeducacion. educacion.es/re2011/re2011_09.pdf]

Moreno Mínguez, A. (2010): "Vida familiar y trabajo en el proceso de transición a la vida adulta de los jóvenes españoles en perspectiva comparada», Revista de Estudios de Juventud, 90, pp.123-141.

Moreno, S. (2009): «Uso del tiempo, desigualdades y ciclo de vida», Política $y$ sociedad, 46 (3), pp. 191-202.

Pollock, G. (2007): "Holistic trajectories: a study of combinend employment, housing and family careers using multiple sequence analysis», Journal of the Royal Statiscal Society, 170, pp.167-183.

PovedA, M. (2006): «»Los lunes al sol» o «los lunes en casa». Roles de género y vivencias del tiempo de desempleo", Cuadernos de Relaciones Laborales, 24(2), 85-110.

Rambla, X. (coord.) y E. Mora; S. Moreno; S. Parella; A.Tarabini y T. Verger (2008): Les fractures de l'estructura social, Bellaterra, Servei de Publicacions UAB.

SALVAdó, T. i SERracant, P. (2003): Forever young. ¿Vulnerabilitat social juvenil o vulnerabilitat social generacional?, ponència presentada al Quart Congrés Català de Sociologia. [http://www6.gencat.net/joventut/catala/sgj/observatori/docs/salvado\%20serracant.PDF] 
SAlvado, T. (2008): «Joves i mercat de treball. Malestar juvenil o malestar generacional?», Nous Horitzons, 189,19-26.

SARACENO, C. (1986): Età e corso della vita. Bolonya: Il Mulino.

SERracant, P. (2009): «Trajectòries juvenils en la Catalunya actual. Una mirada a trvés de l'Enquesta a la joventut de Catalunya», Àmbits, 41, pp. 49-56.

- (coord.) (2013): Enquesta a la joventut de Catalunya 2012. Vol. I-II. [http://www20.gencat.cat/portal/site/bsf/menuitem.77751b51c2cc17 b43f6c8910b0c0e1a0/?vgnextoid=b521f56bdc124410VgnVCM200000 9b0c1e0aRCRD\&contentid=6a376f7521bf2410VgnVCM2000009b0c1e OaRCRD]

Todd, E. (1995): La invención de Europa, Barcelona, Tusquets.

Torns, T. i Moreno, S. (2008): «La conciliación de las jóvenes trabajadoras: nuevos discursos, viejos problemas, mismas soluciones», Revista de Estudios de Juventud, 83. pp. 101-119.

Torns, T.; Carrasquer, P.; Moreno, S. i Borràs, V. (2013): «Career paths in Spain: gendered division of labour and informal employment» Interventions économiques/Papers in Political Economy, 47. [http://interventionseconomiques.revues.org/1935]

Torns, T.; Carrasquer, P.; Parella, S. i Recio, C. (2007): Les dones i el treball la Catalunya: mites $i$ certes, Barcelona, ICD.

VAN DE Velde, C. (2009): «Joventuts d'Europa: trajectòries comparades», Àmbits, 41, pp.42-48. 